\title{
Türkiye'de Yayınlanan Türk Masal Kitaplarının Grafik Tasarım Öğeleri Açısından İncelenmesi: Keloğlan Masalları Örneği
}

\author{
Öğr. Gör. Eda Cerit \\ Doç. Armağan Gökçearslan
}

Makale Geliş Tarihi: 22.03.2016

Yayına Kabul Tarihi: 21.06.2016

\section{Öz}

Bu çalışmada, Keloğlanın Rüyası (2008), Keloğlan ile Geyik Yavruları (2009), Keloğlan ile Büyülü Gömlek (20I0), Keloğlan ve Solmayan Güller Çocuk Kulübü (20II), Keloğlan Hazine Arıyor (20I2), Keloğlan Kargalar Şahı (20I3), masal kitaplarında tipografi, illüstrasyon, illüstrasyon metin ilişkisi, renk, özgünlük, karakterlerin hareketleri (jest, mimik, duygu vs.), kültürel özelliklere yönelik alan uzmanı akademisyen ve illüstratör algıları araştırılmıştır. Çalışmada veri toplama ve analizinde nitel araştırma yöntemi kullanılmıştır.Nitel araştırma için 10 soruluk uzman görüş formu hazırlanmıştır. Nitel veriler 5 akademisyen ve 5 illüstratör ile yapılan yüz yüze görüşme sonucu toplanmıştır. Ses kaydına alınan illüstratör ve akademisyen değerlendirmeleri, daha sonra yazılı hale getirilerek yorumlanmıs ve doğrudan alıntılarla desteklenmiştir. Bulgulara göre, Türkiye'de yayınlanan Keloğlan masal kitaplarının illüstrasyon, renk, yazı fontu ve puntosu, özgünlük, karakterlerin jest, mimik ve duygu hareketleri, kültürel değerler, baskı ve cilt kalitesi açısından yeterince nitelikli olmadı̆̆ı sonucuna ulaşılmıştır. Araştırmanın sonucunda elde edilen verilerden yola çıkarak gelecekte yapılacak araştırmalara ve uygulamalara yönelik öneriler geliştirilmiştir.

Anahtar Kelimeler: Masal, IIllüstrasyon, Grafik, Tasarım, Keloğlan

\section{FAIRY TALE ELEMENTS GRAPHIC DESIGN OF THE BOOKS PUBLISHED IN TURKEY TURKISH EXAMINED IN TERMS OF: TALES OF DOPEY EXAMPLE}

\begin{abstract}
In this study, the perceptions of academics of field expert and illustrators are investigated in terms of typography, illustration, the relationship between illustration and text, color, originality, the characters' movements (gestures, facial expressions and emotion, etc.) and cultural features in the fairy tale books of Keloğlan's Dream (2008), Dopey Deer with Offspring (2009), With Shirt Magical Dopey (2010), Unfading Rose Children's Club (2011), Dopey's Looking for Treasure (2012), Dopey and the King of the Crews (2013). In this study, qualitative research method was used for data collection and analysis. A form of expert opinion including 10 questions was prepared for qualitative research. Qualitative data was collected as a result of face to face interviews with 5 academicians and 5 illustrators. The recorded assessments of illustrators and academicians were interpreted after putting in a written form and supported with direct quotations. According to the findings, the conclusion that the Keloğlan fairy tales books published in Turkey are not qualified enough in terms of illustration, color, text font and font size, originality, gestures, facial expressions and emotions movements of the characters, cultural values, printing and binding quality was reached. Based on the data obtained as a result of the research, the recommendations for future research and applications were developed.
\end{abstract}

Keywords: Tales, Illustration, Graphic, Design, Keloğlan 


\section{Giriş}

Masal, çocuk edebiyatı içinde oldukça önemli bir yere sahip, sözlü anlatım türlerinden biridir. Anlatıldığı dönemi ve kültürü yansıtarak toplumlar arasında kültür taşıyıcılığı yapan masallar, dilden dile, kuşaktan kuşağa aktarılarak varlığını sürdürmektedir. Masallar, zaman ve mekân kavramının olmadığı, genellikle iyilerin ödüllendirildiği, kötülerin ise cezalandırıldığı sonu hep mutlu biten sözlü edebiyat ürünleridir. Masalı birçok araştırmacı farklı cümlelerle fakat aynı anlama gelecek biçimde ifade etmiştir. Sakaoğlu masalı, "Kahramanlardan bazıları hayvanlar ve tabiatüstü varlıklar olan, olayları kendine has bir ülkede cereyan eden, hayal mahsulü olduğu hâlde dinleyenleri inandırabilen bir sözlü anlatım türüdür " biçiminde tanımlamıştır (Sakaoğlu, 2012: 159). Masalı çocuğun hayal dünyasına en yakın anlatı türü olarak tanımlayan Yılmaz'a göre ise masal, "Gerçek dünya ile hayal dünyası arasındaki köprüdür" (Yılmaz, 2010: 72).

Masal kelimesinin etimolojik kökeni "öğretici hikâye" anlamına gelen Arapça "mesel" e dayanmaktadır. Masal, Türk diyarlarında "ertegü, ertek, erteki, çöçek" gibi kelimelerle de ifade edilmektedir (Arıcı, 2001: 59). Türk Dil Kurumu tarafından yayınlanan Türkçe Sözlük'te ise masal, "Genellikle halkın yarattığı, ağızdan ağıza, kuşaktan kuşağa, sürüp gelen, çoğunlukla insanların veya tanrıların başından geçen, olağan dışı olayları anlatan hikâye" şeklinde tanımlanmaktadır (TDK, 2005: 1349).

Masallar sözlü anlatım türü olarak kabul edilse de, anonim masalın yazılı hale getirilmesi veya bir yazarın sanatsal üretimi de sözkonusu olabilmektedir. illk Türk masal kitabı George Jacob'un 1898' de yayınladığı 14 hikâyeden oluşan ve yazıya geçirilen Billur Köşk masalıdır. Tahir Alangu'ya göre, İstanbul kütüphanelerindeki tarihsiz Billur Köşk'lerin en eskisi 1876 yılına kadar görülebilmektedir. Eserin dili biraz sadeleştirilip 1961 yılında Alangu tarafından yayımlanmıştır (Sakaoğlu, 2012: 24). Masal konusunda çalışan bir diğer önemli isim Prof. Dr. Pertev Naili Boratav' dır. Zaman Zaman İçinde (1959) adlı eseri ilk Türkçe masal kitabı özelliği taşımaktadır. Az Gittik Uz Gittik (1969) adlı kitabı ise; Boratav'ın yayımlanan son masal kitabıdır.

Türkiye'nin yanı sıra Dünya masalları arasında yer alan çok sayıda masal ve masal kitabı bulunmaktadır. Kırmızı Başlıklı Kız, Pamuk Prenses ve Yedi Cüceler, Kibritçi Kız, Çizmeli Kedi, Hansel ve Gratel, Fareli Köyün Kavalcısı, Kurt ve Yedi Keçi Yavrusu, Parmak Çocuk, Uyuyan Güzel, Kurbağa Prens, Ormandaki Ev, Külkedisi, Rapunzel, Bremen Mızıkacıları, Uçan Sandık, Deniz Kızı, Çirkin Ördek Yavrusu bu masallardan bazılarıdır. Türkiye'de ise Keloğlan, Nasreddin Hoca, Dede Korkut, Ayşegül masalları gibi masallar öne çıkmaktadır. 


\section{Masal Türleri ve Özellikleri}

Sözlü ve yazılı edebiyat ürünü olarak nitelendirilen masallar, gerek konusu, gerek içerdiği olay, gerekse kahramanına göre farklı biçimlerde gruplandırımaktadır. Hayvan masalları, olağanüstü masallar ve gerçekçi masallar şeklinde yapılan gruplandırma öne çıkan gruplandırma şeklidir.

\subsection{Hayvan Masalları}

Kahramanları hayvanlar bazen de hayvan-insan birleşiminden oluşan kısa anlatımlardır. En önemli özelliği nasihat vermesidir. Amaç bir düşünceyi kabul ettirip ders vermektir (Özkan, 2008: 25). Çocuklar bilmediği birçok soyut kavramı (kurnazlık, azim, güç, kuvvet, cesaret, ahmaklık) hayvan masalları aracılı ile öğrenerek gerçek hayata uyarlayabilirler. Genellikle hayvan karakterleri; aslan, tilki, kurt, eşek ve horozdur. La Fontaine ve Bremen mızıkacıları bu türün en bilinen örnekleri arasındadır.

Çeşitli hayvanlar sembolize edilerek, insanlara ders verme amaç edinildiği için, her hayvanın sembolik bir anlamı vardır. Tilki; kurnazlığı, ayı; ahmaklığı, kurt; gücü, kuvveti, cesareti, hürriyeti, kaplumbağa; azmi vb. sembolize eder. (Tural, Veliyev ve Göçgün, 2002: 135). Bu hayvanlara ek olarak yılan aldatıcılığın, kurt ve kaplan zalim bir insanın, aslan kuvvet ve otoritenin, geyik, leylek ve eşek aptallığın sembolü olarak değerlendirilebilir (Gezer, 2006: 35-36).

\subsection{Olağanüstü Masallar}

Sıra dışı olayların anlatıldığı, ana karakterler, yardımcı karakterler ve konusu tamamıyla hayali olan masallardır. Bu masalların kişileri cinler, periler, devler, ejderhalar, insanlar vb. gibi tabiat dışı varlıklardır. Cinler, periler çoğu kez masallarda insan kılığında görülürler" (Sarıkaya, 2004: 27). Bu tür masallarda hem soyut hem de somut kavramlara sıklıkla yer verilir. Külkedisi masalı olağanüstü masala verilecek en iyi örneklerden biridir.

\subsection{Gerçekçi Masallar}

Olayları ve kahramanları gerçeğe yakın olan masallardır. Gerçekçi masal türünün en bilineni 'Keloğlan' masallarıdır. Gerçekçi masal kahramanları Padişah, Keloğlan ve Köse olarak sıralanabilir.Türk masalları incelendiğinde, padişah ya da bu roldeki kahramanın genellikle kötü ve halkına zulmeden bir karakter taşıdığı görülmektedir. Padişahın yerini zaman zaman vezirlerin, beylerin ve zengin kişilerin aldığı da olur. Padişahın küçük oğlu, kızı veya fakir ailelerin çocukları masalın iyi kararakterleridir (Arıcı, 2004: 165). 


\section{Masal Kitaplarının Tasarımı}

Çocuğun gelişim sürecinde (0-6 yaş döneminde) çocuğa verilen her materyalin dikkatli ve özenli biçimde seçilmesi gerekmektedir. Masal kitapları bu dönemde hem dil ve anlatımıyla hem de görsel ögeleriyle çocuğun yaşamında önemli bir rol oynamaktadır. 6-7 yaş çocuğun estetik beğenisinin temellerinin atılı̆̆ı ve görsel birikiminin oluşmaya başladığı bir dönemdir. Bu nedenle masal kitaplarında grafik tasarım öğelerinin kullanımına dikkat edilmelidir. Masal kitabında illüstrasyon, tipografi, baskı ve cilt, renk iyi bir şekilde hazırlanmış ve çocuğun gelişim özelliklerine hitap eden özellikte olmalıdır (Ünen, 2012: 28).

Masal kitaplarında ilk dikkat çekiciliği sağlayan öğe kapak tasarımında kullanılan illüstrasyon ve masalın ismidir. Bu nedenle illüstrasyonun anlatım dili, masal karakterinin anatomisi, özgünlüğü ve hareketleri başarılı şekilde çocuğa yansıtıımalıdır. Kapakta yer alan illüstrasyon, iç sayfalarda yer alan illüstrasyonlardan daha fazla dikkat çekici olmalıdır, çünkü kapak kitabın ambalajı sayılır. Masalın ismi ve iç sayfalarda yer alan metinlerdeki yazı karakteri, puntosu, rengi, hedef kitlenin yaşı göz önünde bulundurularak seçilmelidir. Algılamada etkili olan kompozisyona kapak ve iç sayfalarda dikkat edilmeli, metin ve illüstrasyon ilişkisi birbirini tamamlayıcı nitelikte olmalıdır. Masal kitaplarının tasarımında çocuklar için önemli olan, metinlerden çok görsellerdir.

Masal kitabı tasarımında dikkat edilmesi gereken öğelerinin başında sayfa ve sayfa tasarımı, illüstrasyon, karakter tasarımı, tipografi, metinillüstrasyon ilişkisi, renk, özgünlük, kültürel değerlerin yansıtılması, baskı ve cilt kalitesi gelmektedir. Bu özelliklere kısaca değinmek gerekirse; kitabın kapağında ve içeriğinde yer alan illüstrasyonlar konuyu ve içeriği yansıtmalıdır. Çocuklar masalı okumadan, dinlemeden illüstrasyona bakarak metini destekleyen bir yorum yapabilmelidir. Metinde geçen her şeyin görselleştirilmesi sıradanlığa yol açarken, çocukların hayal dünyasını kısıtlayabilir. Metinden belirli kesitler sunan illüstrasyonlar çocuklar için daha eğlenceli ve ilgi çekicidir.

Masal kitabı tasarımında; görsellerin kullanılması iletişimi, düşünmeyi ve öğrenmeyi desteklemektedir. Metin ve görselin birbirini desteklemesi, bilginin kolay algılanabilir, kavranabilir ve hafızada kalıcı olmasında etkili olmaktadır. Bu açıdan düşünüldüğünde, resimsel örneklerin çizimine, rengine, özgünlüğüne, metinle olan ilişkisine, kompozisyonuna ve tekniğine gereken özen gösterilmelidir.

Renk, ayırt ediciliği, yön göstericiliği ve vurgulayıcılığı ile masal kitaplarının 
değerlendirilmesinde en önemli öğelerinden biridir. Kapak ve iç sayfalar da yer alan illüstrasyonlar ve yazılardaki renkler kitabın algılanabilirliğini ve dikkat çekiciliğini arttırmaktadır. Tasarımın en önemli yapı taşlarından birisi olan renkler, dikkat çekme, duygulara etki etme, bir sembole değişik değer ve anlamlar yüklemek açısından büyük oranda etki gücü sağlarlar ve neredeyse tüm renkler, insanlar üzerinde değişik etkiler yaratır, değişik duyguları harekete geçirir (Selvi, akt: Işıklı, 2012: 36).

Arka fon rengi ve yazı-illüstrasyon rengi birbirinin tamamlayıcısı olmalı, okumayı ve algılamayı olumsuz etkilememelidir. Masal kitaplarında renklerin yalnızca bilinen ana tonunun kullanılması, ara ton arayışına gidilmemesi, ortaya sanatsal değer taşımayan, estetikten uzak eserler çıkarabilir. Masal kitaplarında illüstrasyon ve renk ile birlikte düşünülmesi gereken bir diğer öğe tipografidir. illüstrasyonun anlatım dili metinde, metinin anlatımı illüstrasyonda saklıdır. Metin illüstrasyonları açıklayıcı, anlatıcı nitelikte olmalıdır. Çocuk metinden anlayamadığını illüstrasyonlara bakarak anlayacağından, illüstrasyonda hareket ve anlatım bütünlüğü kurulmalıdır. Görsel ifade bütünlüğü ve metinsel ifade bütünlüğü iyi olmalı ki doğru algılama sağlanabilsin (Arslan, 2008: 1).

Görsel algılamaya etkisi olan tipografi kadar önemli olan bir diğer öğede masal karakterleridir. Masallardaki karakterleri, çocukların karakterlerle kendilerini özdeşleştirmeleri, rollerini benimseyip hayatlarına geçirmeleri açısından oldukça önemlidir. Karakterlerin davranışları çocuklara olumlu ya da olumsuz örnek olabilmektedir. Bu nedenle, edebi olarak yazılıp, anlatılan karakter özellikleriyle, görsel olarak tasarlanan karakterin özellikleri aynı olmalıdır.

Masal karakterlerinin hareketlerinin (jest, duygu, mimik vs.) doğru yansıtılması, anlatıma hareket ve canlılık kazandırırken, akılda kalıcılığı da artırmaktadır. Çocukların masal karakterlerini sevmesi, onları kendine örnek alması karakterlerin ifade biçimlerine bağlıdır. Gülen bir karakter gülmüyor, ağlayan bir karakter ağlamıyorsa çocukta anlam karmaşasına yol açabilir.

Masal kitaplarındaki anlatımlar ve yapılan tasarımlar özgün olmalıdır. Başka bir masalın anlatımı ve karakter tasarımıyla benzerlik taşımamalıdır. Etik değerlere bağı kalarak yeniden yazılmalı ve tasarlanmalıdır. İlk kez ve farklı tasarlanmış bir masal karakterini gören çocuk masala daha fazla ilgi göstermekte ve masaldan daha çok zevk almaktadır. Masalların çocuklara sağladığı yarar göz önüne alınarak, yazar ve çizer masalların yazımına ve illüstrasyonlarına gereken değeri vermelidir. 
Baskısı yapılacak masal kitabında kâğıt seçimine de dikkat edilmelidir. Görselleri ve yazıları arka tarafa geçirerek algılamayı ve okumayı zorlaştıran, ince gramajlı kâğıtyerine kitabın rafömrünü uzatan ve kitabın dayanıklılığını arttıran kalın gramajlı kâğıt kullanılmalıdır. Fakat Türkiye'de maliyetin ön planda tutulması buna engel olmaktadır. Günümüzde yayınlanan pek çok masal kitabı genellikle ince gramajlı kâğıtlara basıımıştır. Kâğıt kalitesi ile birlikte düşünülmesi gereken ciltleme yönteminin seçiminde de, kullanışlılık ve dayanıklılık dikkate alınmalıdır.

"Geçmişte bir sanat dalı gibi saygı ve önem verilen ciltçilik, halen ustalık gerektiren bir konudur. Her ne kadar iyi bir baskı öncesi hazırlık ve baskı süreci geçirmiş olsun, ilk okumada elinizde dağılarak parçalanan bir kitap değerini bir anda yitirir" (Uçar, 2004: 186). Ciltleme yöntemi küçük yaşlardaki çocukların bilinçsiz kitap kullanımı düşünülerek seçilmelidir.

\section{Araştırma Modeli}

Araştırmanın amacına yönelik nitel veri analiz tekniklerinden "betimsel analiz" kullanılmıştır. Nitel verilerde, alan uzmanlarının ve illüstratörlerin Keloğlan masal kitaplarının illüstrasyon, renk, yazı fontu ve puntosu, baskı ve cilt kalitesi, karakterlerin jest, mimik ve duygu hareketleri, metin ve illüstrasyon ilişkisi, özgünlük ve kültürel özelliklere ilişkin düşünceleri yer almaktadır.

\subsection{Evren ve Örneklem}

Araştırmanın evrenini, 2008-2013 yılında Türkiye'de yayınlanan İlkokul 1.ve 2. sınıf seviyelerindeki " 46 Keloğlan" masal kitabı oluşturmaktadır. Anadolu kültürünün akıllı, sevimli komik masal karakteri olan Keloğlan zorluklarla mücadelenin kahramanıdır. Her güçlüğe pratik zekâsı ile çözüm bulur. Keloğlan, "Arzu edilene ulaşma ve imkânsızı gerçekleştirme fonksiyonunu yerine getirme başarısını gösteren bir tiptir" (Bilkan, akt: Şimşek, 2006: 5-6). Kendine güvenen, iyiliksever, mücadeleci ve güler yüzlü Keloğlan'ın masallarında yan karakterler olarak eşeği ve anası yer alır.

Tipe ait özellikler ona halk tarafından atfedilmiş, böylece kalıclık ve ebedilik kazanmıştır. Halk, onu görmek istediği kalıplar içinde kabul etmiştir. Bu nedenle de halkın gözü, kulağı, hissiyatı, aklı, yargı gücü, zekası ve sesi olma görevini yürütmüştür. Hiçbir tip, ferdi bir şahsiyet olarak ifade edilemez. Tipin şahsiyeti cemiyetin ve bu cemiyette yasayan insanların ortak eğilimlerine göre şekillenir.Toplumdaki gelişim ve değişime paralel olarak tipe yeni unsurlar eklense de, bu durum hiçbir zaman tipin belirgin vasıflarını değiştirmez. Tipin yaratılması ve tip olarak kabul edilmesinde en önemli etken, halkın yarattığı tipe sahip çıkması ve onu zamanın şartlarına göre 
yenileyebilmesidir (Yıldırım, akt: Harmancı, 2010: 38).

Geçmişten günümüze çoksayıda Keloğlan masalıbulunmaktadır. Keloğlanın Eşeği (1955), Akıl kutusu (1953), Keloğlan ile Köse (1958), Keloğlan ile Cim Cim Arısı (1959), Keloğlan ve Haydutlar (1962), Keloğlanın Meraklı Masalları (1975), Keloğlan Masalları (1986), Aslan keloğlan (1987), Keloğlan Tembel Oğlan (1996), Keloğlan ile Cambazlar (1997), Keloğlan (2001), Keloğlan ile Padişah (2002), Keloğlan ile Dev Anası (2003), Keloğlanın Rüyası (2004), Padişahın Küçük Kızı ile Keloğlan (2005), Gizli Hazine (2006), Keloğlanın Tilkisi (2008), Afrikalı Keloğlan (2009), Keloğlan ile Güle Oynaya (2011), Padişahın Kayıp Kızları (2012), Keloğlan Aramızda (2013), Keloğlanın Sofrası (2014) vs. masalları yayınlanmıştır.

Keloğlanın bilinen kendine özgü tipinin dışına çıkmak pek mümkün değildir. Kafasının kel oluşu, belindeki kuşağı, kafasındaki sarığı, ayağındaki çarığı, sırtındaki yeleği farklı teknik, boyut, renkte birçok çizer tarafından resmedilmiştir. Duygu Malatyalıoğlu'nun (Resim 1), Mustafa Delioğlu'nun (Resim 2), illüstrasyonlarında örneklerini görmek mümkündür.

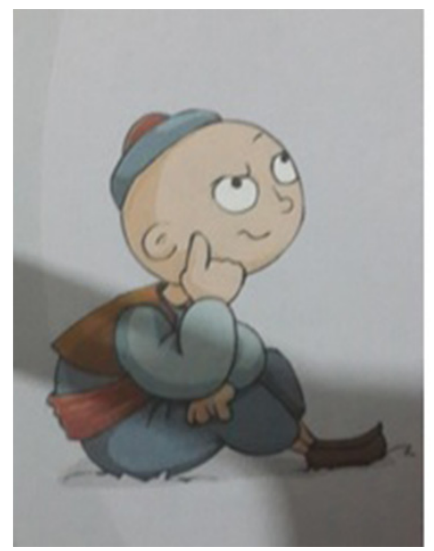

Resim I. Muhterem Tortop-Duygu Malatyalığlu-Anıl Tortop, Keloğlan Avcı Masalı, 2008, Bilgisayar, 14 × $24 \mathrm{~cm}$. 


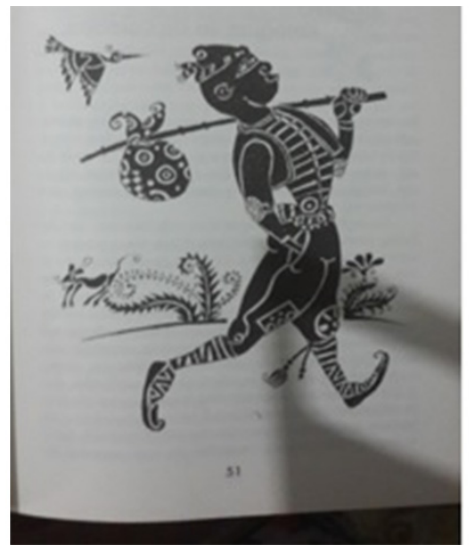

Resim 2. Tahir Alangu-Mustafa Delioğlu, Keloğlan Masalları Kitabı, 2013, Akrilik, $13.5 \times 19.5 \mathrm{~cm}$.

Araştırmada veriler yarı yapılandırılmış görüşme formu kullanılarak uzmanlarla yüz yüze görüşme biçiminde toplandığı için sözkonusu 46 kitaptan rastgele bir seçim yapılmıştır. Buna göre kitaplar numaralandırılarak kura yöntemi ile her yıldan seviyesi 1. ve 2. sınıf olan birer kitap alınarak, 6 masal kitabı seçilmiştir. Seçilen 6 adet Keloğlan masal kitabı bu araştırmanın örneklemini oluşturmaktadır.

Kargalar Şahı, Keloğlan Hazine Arıyor, Keloğlan ve Solmayan Güller Çocuk Kulübü, Keloğlan ile Büyülü Gömlek, Keloğlan ile Geyik Yavruları, Keloğlanın Rüyası masal kitapları kura yöntemi ile seçilen kitaplardır.

\subsection{Verilerin Toplanması}

Bu çalışmada veri toplama aracı olarak, Yıldırım ve Şimşek'in (2008) nitel çalışmalar için önerdiği görüşme formu yaklaşımı kullanılmıştır. Farklı kişilerden benzer bilgileri alabilmek amacıyla kullanılan görüşme formu yaklaşımı, hem önceden hazırlanmış soruları sorma, hem de görüşme sürecine göre ek sorular sorma özgürlüğünü araştırmacılara tanımaktadır.

Görüşmeler katılımcıların çalıştıkları okulda ve atölyede gerçekleştirilmiştir. Görüşmeler yaklaşık 1 saat sürmüş akademisyenlerin ve illüstratörlerin değerlendirmelerises kayıt cihazı ile kaydedilerek daha sonra çözümlemeleri yapılmıştır. Çalışmaya katılan 5 akademisyen LR, IKK, NE, SD, GDE ve 5 illüstratör BG, SD, EK, AIA, MD şeklinde kodlanmıştır.

Araştırmada veri toplama amacıyla yarı yapılandırılmış görüşme formu kullanılmıştır. Soruların her biri farklı verileri elde etmek üzere hazırlanmıştır. 
Görüşme soruları literatür taramasından sonra uzman görüşü alınarak düzenlenmiştir. Görüşme formunda yer alan toplam on iki soru uzman düzeltmeleri sonucu ona indirilmiş ve içerik geçerliliği sağlanmıştır.

illüstratörlere ve alanında uzman akademisyenlere; hedef kitlenin konuyu algılaması, illüstrasyonun dikkat çekiciliği, renk seçimi, metin ve illüstrasyon ilişkisi, yazı karakteri ve puntosu, özgünlük, karakterlerin jest, mimik ve duygu hareketleri, kültürel değerler, baskı ve cilt kalitesi ile ilgili toplam 10 soru sorulmuştur.

\subsection{Geçerlik}

Araştırmada geçerliği sağlamak amacıyla, görüşme formunda yer alan 10 adet soru grafik tasarım alanında çalışan 3 akademisyen ve eğitim bilimleri alanında çalışan 2 akademisyen tarafından gözden geçirilmiş ve geçerliği tespit edilmiştir.

\subsection{Verilerin Analizi}

Çalışmanın nitel analizi alan uzmanı akademisyenlerin ve illüstratörlerin görüşme formundaki 10 adet açık uçlu soruya verdikleri yanıtlar incelenerek yorumlanması şeklinde olmuştur. Ses kayıt cihazı ile kayıt altına alınan görüşme verileri araştırmacı tarafından önce bilgisayar ortamında yazılı hale getirilmiş daha sonra da nitel araştırma tekniklerden betimsel analiz kullanılarak çözümlenmiştir.

Uzmanlara sorulan sorular doğrultusunda 9 başlık altında; hedef kitle, illüstrasyon, renk, metin ve illüstrasyon ilişkisi, tipografi (yazı fontu ve puntosu), karakterlerin hareketleri (jest, mimik, duygu vs.), özgünlük, kültürel özellikler, baskı ve cilt kalitesi temaları belirlenmiştir. Görüşme yapılan 5 akademisyen ve 5 illüstratör, akademisyen 1,2,3,4,5 ve illüstratör $1,2,3,4,5$ olarak kodlanmıştır. Görüşme verileri ortaya çıkan temalar altında düzenlenmiş ve tanımlanmıştır. Yapılan betimlemeler görüşme yapılan uzmanlardan alınan doğrudan alıntılarla zenginleştirilmiştir.

\subsection{Bulgular ve Yorumlar}

Makale çalışması kapsamında örneklem olarak alınan 6 adet Keloğlan masal kitabı, akademisyen ve illüstratör tarafından; illüstrasyon, illüstrasyon ve metin ilişkisi, tipografi (yazı fontu ve puntosu), renk, özgünlük, karakterlerin jest, mimik ve duygu hareketleri, kültürel değerler ile baskı ve cilt kalitesi bağlamında incelenmiştir. Böylece illüstratör ve akademisyenlerin yaklaşımları ortaya konularak, konunun çok boyutlu olarak akademik tartışmaya açılması hedeflenmiştir. 


\subsubsection{Hedef Kitle}

Örneklem içerisinde yeralan Keloğlan masal kitaplarında mevcut illüstrasyonların konunun bütünlüğünü aktarma ve hedef kitlenin konuyu algılaması açısından kısmen yeterlilik sağladığı tespit edilmiştir. Oysa masal metninde geçen öykülerin illüstrasyonlar aracılığı ile daha iyi kavranıp öğrenildiği kabul edilmektedir. Profesyonel illüstratörlerin yaptığı çalışmaların kitabı estetik, sanatsal ve çekici hale getirerek konunun algılanmasında olumlu rol oynadığı varsayılmaktadır. Örneklemde yer alan masalkitaplarınıdeğerlendirenillüstratörlerde, Keloğlanmasalkitaplarındaki illüstrasyonların hedef kitlenin konuyu algılaması bakımından sorunlu olduğunu belirtmiştir. illüstratör 3'ün yorumu şu yöndedir: "Keloğlan ve Solmayan Güller Çocuk Kulübü masal kitabının hedef kitle açısından dikkate değer bir çalışma olduğunu düşünmüyorum. Değerlendirilen diğer kitaplar (Keloğlan Hazine Arıyor, Keloğlan ile Büyülü Gömlek, Keloğlanın Rüyası, Keloğlan ile Geyik Yavruları, Kargalar Şahı) konuyu anlatıyor."

Masal kitaplarında genellikle vücut ve el oranlarında anatomik ve teknik hatalar bulunduğu, bu nedenle konunun algılanmasında sorun oluşturduğu ifade edilmiştir. Akademisyenlerin kitaplarda yer alan illüstrasyonlara ilişkin tespitleri de benzer şekildedir. Kitapların güncel olmadığı, biçimlemede görsel kimliği ileri götüren, çocuğun hayal dünyasını geliştiren çalışmalar olmadığı aktarılmıs, illüstrasyonların çocuğun hoşuna giden, hayal kurmasını sağlayan çalışmalar olması gerektiği belirtilmiştir. Türkiye'deki yayınlar ile yurt dışındaki yayınlar karşılaştııılmış, bu kapsamda Türkiye'deki yayınların geleneksel ve geri olduğu aktarılmıştır.

\subsection{2 illüstrasyon}

Akademisyenler ve illüstratörler, örneklem kapsamında yer alan kitaplarda kapak sayfalarında yer alan illüstrasyonların genel olarak sıradan resmedildiğini, kapakların etkileyici ve vurucu olmadığını, illüstrasyonlar da üslup farkııı̆̆ı bulunmadığını aktarmıştır. Hazır şablonlar kullanıımadığında kitapların daha başarılı olacağı konusunda akademisyenler ve illüstratörler hem fikirdir.

Akademisyenveillüstratördeğerlendirmelerinebakıldığındaillüstrasyonların dikkat çekici olmadığı, illüstrasyonlarda perspektif ve anatomik hataların olduğu ve bunun dikkat çekiciliği olumsuz yönde etkilediği, karakter tasarımının özgün ve yalın olmadığı, sürekli aynı çizimlerin farklı sayfalarda defalarca tekrar ettiği, illüstrasyonlarda yapılan oran-orantı hatalarının başarılı bir masal kitabının ortaya çıkmasına engel olduğu, yapılan anatomik hataların çocuğun görsel algılamasını zorladığı ifadeleriyle karşılaşıımıştır. 
Görüşmeye katılan illüstratör 5 , değerlendirilen kitaplardaki çizimler konusunda şunları söylemiştir: "Türkiye'deki masal kitapları yurt dışındaki masal kitapları kadar profesyonel işler değiller. İlüstrasyonların birçoğunu alanında uzman kişilerin yapmadığı, tasarım aşamasında grafik tasarım öğeleri ve grafik tasarım ilkelerinden yararlanılmadığı ortadadır."

Sektörde çalışan akademisyen 1 ise, "masal kitaplarındabirçok anatomik ve teknik hata yapılmış, grafik tasarım öğeleri ve ilkelerinden yararlanılmamış, anatomik ve teknik açıdan Batı ülkesi çocuk masal kitaplarında olduğu kadar başarılı değiller, en önemlisi vücut ve el oranlarındaki hatalardır" açıklamaları ile konuyu desteklemektedir.

Akademisyen ve illüstratörler arka arkaya basit ve aynı desenlerin olması, yanyana gelen sayfalardaki desenler ile sayfalar arasında bütünlük kurulamaması, renk ve desen devamlılığının olmamasının, algılamada olumsuz bir etki bırakırken; süreklilik hissi vermediği için de dikkat dağılmasınanedenolabileceğini varsaymışlardır. Yapılandeğerlendirmelerde mekân ve eşya resimlemelerinde de büyük eksiklikler olduğu ifade edilmiştir.

Görüşme yapılan illüstratör ve akademisyenler günümüzde artık 3D uygulamaların çizgi film ve animasyon çalışmalarında sıklıkla görüldüğünü, fakat değerlendirilen Kargalar Şahı masal kitabındaki (Resim 3), uygulamada karakter illüstrasyonlarının donuk, duygusuz ve renk seçimlerinin yanlış olduğunu belirtmişlerdir. illüstratör 3, "karganın olduğu tüm sahnelerde, kargaya ışık efekti verilmediği için karga simsiyah görünüyor ve koyu renkli arka fon ile birleşince kayboluyor" ifadesi ile renk seçimi konusunda olumsuz bir eleştiride bulunmuştur.3D konusunda olumlu değerlendirme yapan illüstratör 5 'in "kapakta parlaklık verilmiş, bu da hoşluk, çekicilik yaratmak için artık günümüzde kullanılmaktadır. Renkler canlı gayet iyi" ifadesi olumlu bir yaklaşımdır.

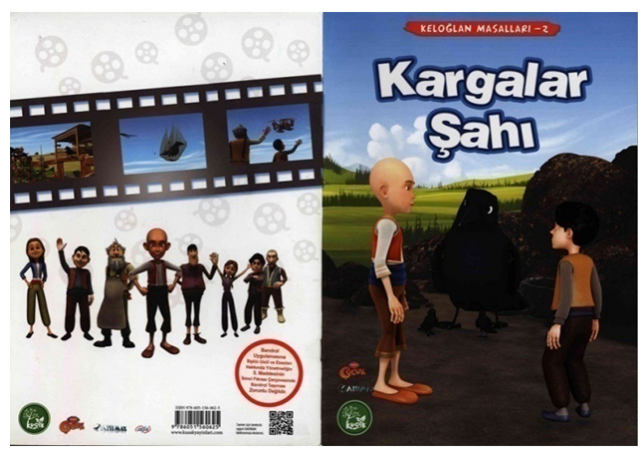

Resim 3. Orhan Bilir, Volkan Yiğit, Kargalar Şahı Masal Kitabı, 2013, Bilgisayar, $19.5 \times 27 \mathrm{~cm}$. 


\subsubsection{Renk}

Görüşme yapılan illüstratörler ve akademisyenler masal kitaplarında renk seçimi ile ilgili gerekli özenin gösterilmediğini belirtirken, işin kolayına kaçarak renklerdeki ara tonları bulmak yerine rengin tek tonunun tercih edildiğini belirtmişlerdir. Çocukların gördüğünü algılamasında etkili olan renk seçiminde akademisyen 2' nin düşünceleri şu şekildedir: "Renk uyumu bazı masal kitaplarında çok kötü, çocuklar için ille de şu renk olmalı diye bir kural mevcut değil. Ama renkler birbirine uyumlu olmalı. Ara tonlar da kullanılmalı ki sert tonları yumuşatsın. Çocuğun tonu budur denilemez. Renkler kendi içerisinde ahenk içerisinde olmalıdır."

Renklerin hazır tonlarda kullanımı konusunda illüstratör 2'nin "Seçilen örneklerin tamamı bilgisayarda çizilip boyanmış örnekler renklerin ham ve çiğ olduğunu düşünüyorum" ifadesi renklerin hazır tonlarda kullanımının olumsuzluğuna vurgu yapmaktadır. Görüşme yapılan illüstratör 1'in "Renklerde uyum ve bütünlük yok, gözünüzü biraz kıstığınızda renkteki denge ve bütünlüğü görürsünüz" sözleri dikkat çekicidir.

Görüşme yapılan akademisyen ve çizerler; tipografide ve arka fonda çocukların okumasını zorlaştıran renk seçimlerinden uzak durulması gerektiğini belirtmişlerdir. illüstratör 4'ün "Kitaplarda arka fonlar çok başarısız. Resmin üzerine yazılar gelmiş. Başlığın fon ile karıştığı sayfalar var. Grafik düzenden son derece yoksun masal kitapları var" ifadesi konuyu destekleyici niteliktedir.

\subsubsection{Metin ve illüstrasyon ilişkisi}

Akademisyen ve illüstratör değerlendirmeleri sonucunda genel olarak illüstrasyonun metinde anlatılanı desteklediğini fakat bazı kitaplarda yetersiz kaldığını, metinle görselin birbiri ile bütünlük içerisinde olması ve çocukların metinde geçen anlatımların bir bölümünü de olsa görselde görebilmesi gerektiğini belirtmişlerdir. Bu konuda illüstratör 1'in görüşü şöyledir: "Metinde geçenin aynısını koymak mantığıyla yapılmış kitaplar. îllüstratörün görevi öyküyü zenginleştirmektir. Bu verilen minik ayrıntılarda olabilir. Sizin bir şey eklemenizle de olabilir. Çocuklar eksik resimlere karşı son derece dikkatli ve duyarlıdırlar."Bu konuda farklı bir değerlendirme yapan illüstratör 5'in "Genel anlamda metin ve illüstrasyon birbirini destekliyor" açıklaması olumlu bir değerlendirme olarak görülmektedir.

\subsubsection{Tipografi (Yazı Fontu ve Puntosu)}

Kendileriyle görüşülen illüstratörler bazı masal kitapları için, metinin puntosunun küçük, kapak yazı karakterinin çok zayıf olduğunu, yazının 
resmin üzerine geldiğinde okunması rahat olsun diye bazı kelimelerin farklı renklerde yazıldığını ve bu nedenle sayfa bütünlüğünün bozulduğunu belirtmişlerdir. Çocukların yaşına uygun yazı karakteri ve punto seçiminin yapılmadığı, okumakta zorlanan çocuğun doğal olarak kitaptan soğuyacağı, görsellerin dikkat çekiciliği kadar yazılarında okunaklı olmasının algılamada etkili olacağı belirtilmiştir. Bu konuda illüstratör 2'nin yorumu şu şekildedir: "Sayfalarda arka fon ile yazı karışmış ve okumayı zorlaştırıyor. Sadece doğru yazı karakteri ve punto seçimi yeterli değildir aynı zamanda illüstrasyonun arka fon ile uyumu önemlidir."

Yazı karakteri ve puntosu hakkında olumlu değerlendirmeler de bulunan illüstratör 5 "Bence yazı karakteri ve puntosu yeterli. Çok büyük olması gerekmiyor. Çocukların dikkatini dağıtır. Yazı konusunda MEB'nın dayatması bana yanlış geliyor. Düz okunabilir yazı seçimi birçok masal kitabında tercih edilmiştir. Keloğlan ile Geyik Yavruları masal kitabını (Resim 4), Keloğlan ve Solmayan Güller Çocuk Kulübü masal kitabını (Resim 5), çocuklar okuyamaz diye düşünmesinler; okurlar. Fakat görsel açıdan daha zengin yazı fontları kullanılabilir" açıklaması ve akademisyen 4'ün "genel olarak kitaplardaki yazı karakteri ve puntosu hedef kitlenin yaşına uygunluk bakımından iyi" ifadesi konuyla ilgili olumlu değerlendirmelerdir.

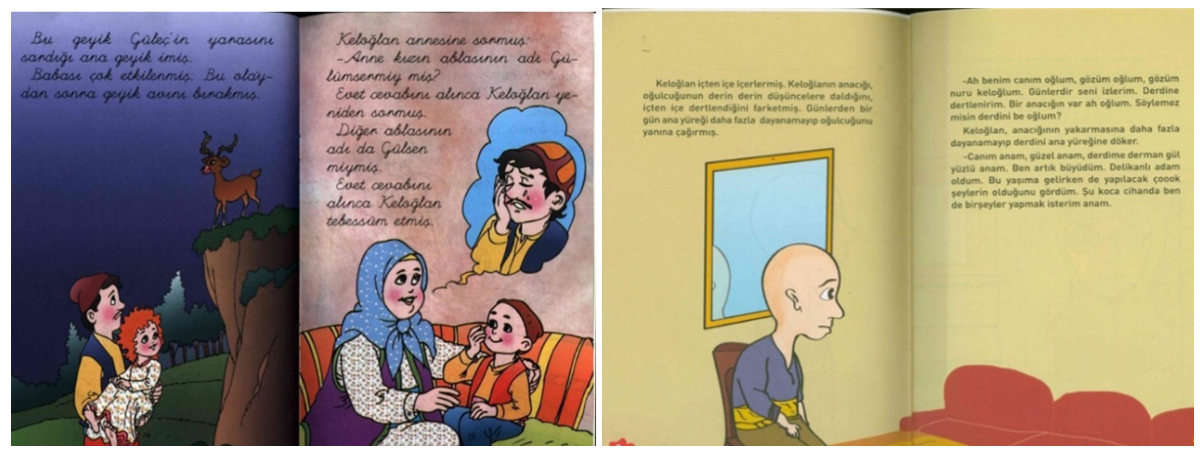

Resim 4. A. Enis Turan- Çizgiötesi, Keloğlan ile Geyik Yavruları Masal Kitabı, 20I0, Bilgisayar, $16.5 \times 24 \mathrm{~cm}$.

Resim 5. Gülseren Gümüş-Yakup Çilesiz, Keloğlan ve Solmayan Güller Çocuk Kulübü Masal Kitabı, 2006, Bilgisayar, 16 × $24 \mathrm{~cm}$.

Bazı akademisyen ve çizerler, MEB'nın müfredat gereği el yazısı öğretmesinin ve bazı masal kitaplarında el yazısı karakterinin tercih edilmesinin çocukların kitabı okumada zorlanmasına neden olduğunu belirtmişlerdir. Bu konuda illüstratör 1, "El yazısına karşıyım. Çocuklar düz yazıya geçtiklerinde çok zorlanıyorlar" sözleriyle konuya açıklık getirmiştir. 
Akademisyen 1 'in "Kitaplarda kullanılan yazı fontu (yazı tipi) ve puntosu hedef kitlenin yaşı açısından olumlu görünmektedir, zaten 1. ve 2. sınıf çocuklarına müfredat gereği el yazısı öğretilmekte ve öngörülmektedir, bu kitaplarda da mevcuttur" açıklaması olumlu bir yaklaşımdır.

\subsubsection{Karakterlerin Hareketleri (Jest, Mimik, Duygu vs.)}

Masal karakterlerinin, hareketlerinin (jest, mimik, duygu, vs.) yansıtılması ile ilgili akademisyen ve illüstratörler değerlendirmelerinde karakterlerin hareketlerinin doğru olarak yansıtıldığını belirtmiş ancak mimiklerde tutukluk ve donukluk olduğunu aktarmışlardır. Kahramanların başarılı olarak resmedildiğini düşünen akademisyenlerde vardır. Örneğin; tiplemelerin bazı kitaplarda çok başarılı olduğunu söyleyen akademisyen 2, "Keloğlan Hazine Arıyor masal kitabında (Resim 6), tiplemeler, renk seçimi, hareket halindeki figürler, ifadeler, ejderha tanımlaması son derece başarılıdır. Masal karakterlerinin hareketleri (jest, mimik, duygu) o kadar kötü değil" ifadesiyle konuya ilişkin olumlu düşüncesini belirtmiştir.

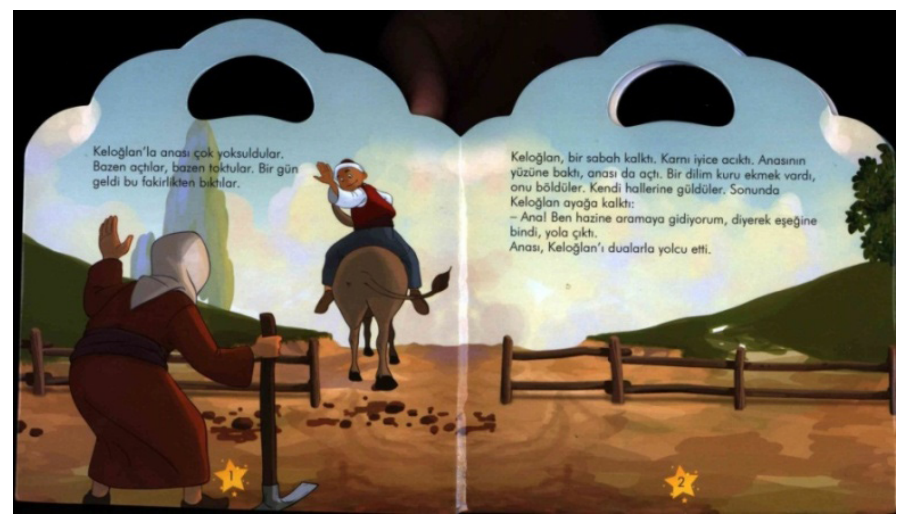

Resim 6. Ekrem Bektaş- Mahmut Acar, Keloğlan Hazine Arıyor Masal Kitabı,2012, Bilgisayar, $19 \times 21 \mathrm{~cm}$.

Karakterlerin hareketleri ile ilgili olumlu ve olumsuz değerlendirme yapan illüstratör 3'ün yorumu şu şekildedir: “Değerlendirilen kitaplarda karakterlerin hareketleri doğru yansıtılmış fakat Kargalar Şahı masal kitabında (Resim 7), karakterlerin hareketleri donuk olmakla birlikte doğru yansıtılmış," akademisyen 1'in ise, "Keloğlan ile Geyik Yavruları masal kitabında (Resim 8), karakterlerin hareketleri (jest, mimik, duygu vs.) doğru yansıtılmıştır; ancak kapak sayfası ve 6. sayfada Keloğlan geyiğe doğru ok atarken, gözlerinin kapalı oluşu bir hareket hatasıdır" açıklamaları dikkat çekicidir. 


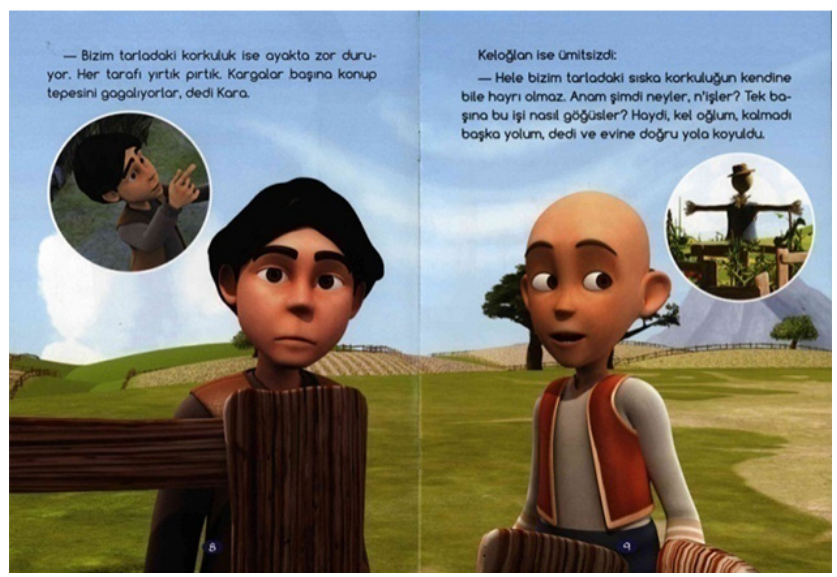

Resim 7. Orhan Bilir, Volkan Yiğit, Kargalar Şahı Masal Kitabı, 2013 , Bilgisayar, $19.5 \times 27 \mathrm{~cm}$.

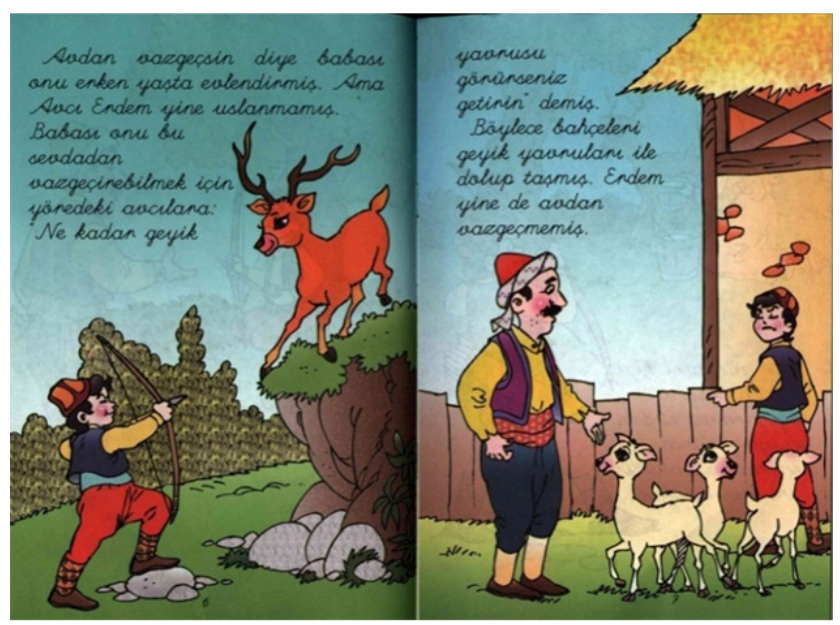

Resim 8. A. Enis Turan-Çizgiötesi, Keloğlan ile Geyik Yavruları Masal Kitabı, 2010, Bilgisayar, $16.5 \times 24 \mathrm{~cm}$.

\subsection{7. Özgünlük}

Akademisyen ve illüstratörler, Türkiye'deki birçok masal kitabında hazır şablonlar kullanıldığı için masal kitaplarının özgünlükten uzak olduğunu, değerlendirilen Keloğlan kitaplarında da aynı sorununun devam ettiğini belirtmişlerdir. Akademisyen 2'nin "Keloğlan Hazine Arıyor masal kitabında (Resim 9), sayfa 8' de saçını tarayan kız figürü Raphunzel alıntısını çağrıştırıyor" açıklaması karakter tasarımında özgünlüğün olmadığını vurgulamaktadır. 


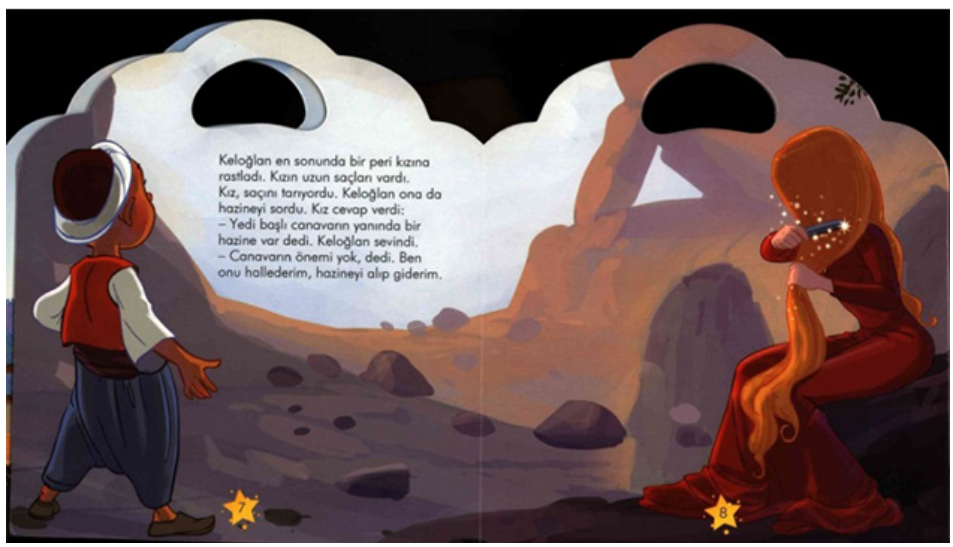

Resim 9. Ekrem Bektaş-Mahmut Acar, Keloğlan Hazine Arıyor Masal Kitabı, 2012, Bilgisayar, $19 \times 21 \mathrm{~cm}$.

Illüstratör ve akademisyen değerlendirmelerinde, Türk kültürünü yansıtan masal kitaplarında Türk motiflerinden yararlanmak yerine bilgisayarın hazır motiflerinden yararlanılarak tasarımlar yapıldığını ve bu nedenle özgünlük kavramından bahsetmenin mümkün olmadığını belirtmişlerdir. İllüstratör 4'ün konuya yaklaşımı şöyledir: Keloğlan ve Geyik Yavruları masal kitabında bizim kültürümüzle ilgili motifler, desenler kullanılsa çok daha iyi olurdu."

Akademisyen 1'in özgünlük konusundaki yorumu şu şekildedir: "Keloğlan ve Solmayan Güller Çocuk Kulübü (Resim 10), masal kitabı karakteri özgün nitelik taşımamaktadır. Kitap içerisinde de kitaba özgü olmayan başka bilinen karakterler (Hacivat ve Karagöz, Şirinler, Nasreddin Hoca) bilgisayar ortamından kopya olarak alınıp yapıştırılmıştır. Bu görüntüsüyle kitap hiç özgün değildir."

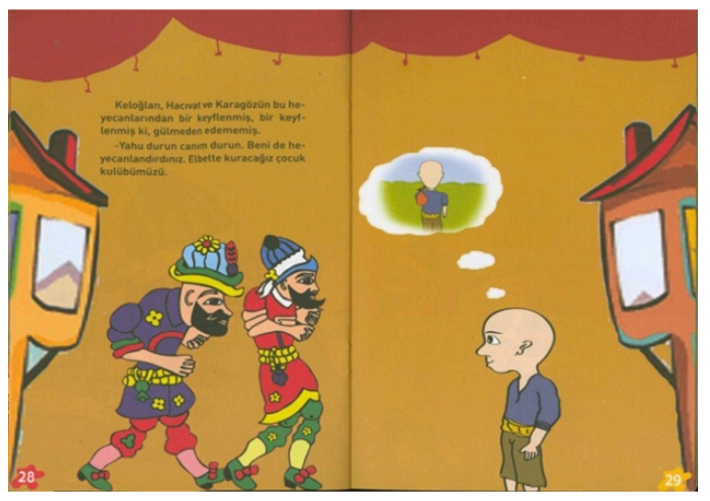

Resim 10. Gülseren Gümüş-Yakup Çilesiz, Keloğlan ve Solmayan Güller Çocuk Kulübü Masal Kitabı, 2006, Bilgisayar, 16 × $24 \mathrm{~cm}$. 


\subsubsection{Kültürel Özellikler}

Akademisyen ve illüstratörler, kültürel özelliklerin yeterince önemsenmediğini, masallarda geçen kıyafetlerin çok iyi incelenmediğini, bazı kitapların Türk kültürü yerine Batı kültürünü yansıttığını, kültürel açıdan bilinçsizce bir akışın sözkonusu olduğunu belirtmişlerdir.

illüstratör 4, "metinde karakterin kıyafeti şöyle olmalı böyle olmalı diye yazmaz. Bu konuda illüstratörün araştırma yapması gerekir. Burada yayınevinin illüstratöre verdiği süre önemlidir. Yeterli zaman verilmeyen birçok illüstratör hazır kalıpları kullanabilmekte ve özgünlük kavramı değerini yitirmektedir" açıklaması dikkat çekicidir.Bu konuda illüstratör 3'ün yorumu ise şu şekildedir: "Keloğlan Hazine Arıyor masal kitabı bence kültürel özellikleri yansıtıyor. Anadolu kıyafetleri, kasketleri verilmiş. Biraz fantastik olarak peri kızındaki kıyafet ve saçlarda biraz yabancı karakterlerden etkilenme var." Görüşme yapılan bazı illüstratörler kültürel özelliklerin yansıtıması konusunda kitapların çok yeterli olmadığını ama bazı değerlerimizden az da olsa söz edildiğini belirtmektedirler. illüstratör 2, "merhamet, yardımlaşma, paylaşma, vefa gibi özelliklere değinmelerini olumlu buluyorum" sözleriyle konuya olumlu yaklaşmıştır.

Görüşme kapsamında masal kitaplarının kültürel özellikleri yeteri kadar yansıtmadığı ön plana çıkarken, illüstratör 5 'in "Kargalar Şahı masal kitabı (Resim 11), kültürel özellikleri yansıtıyor. Fakat ağaçlar bizim kültürümüze yakın değil. Kayın, kekik vb. ağaçlar olabilirdi. Ağacı yapay buldum. Keloğlan'ın Rüyası isimli kitapta (Resim 12), yer alan devin belinde kuşak olabilirdi. Karakter biraz Avrupai kaçmış. İllüstratör masalın geçtiği dönemi ve özelliklerini araştırıp çalışmalarına yansıtırsa çocuklar o döneme gidip masalı düşüncelerinde yaşayıp canlandırabilirler"açıklamaları konuyu desteklemektedirler.

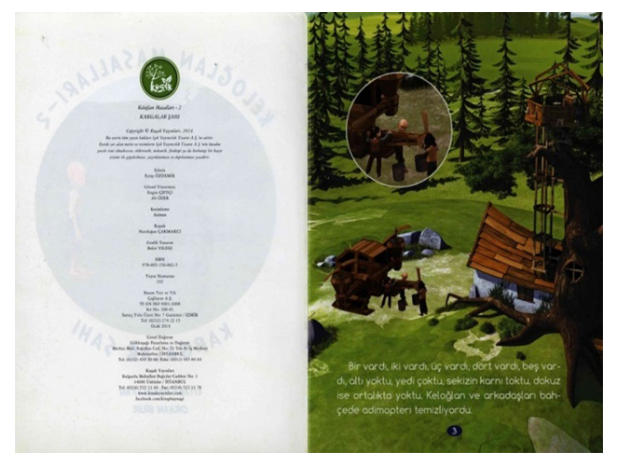

Resim II. Orhan Bilir-Volkan Yiğit, Kargalar Şahı Masal Kitabı, 20/3, Bilgisayar, $19.5 \times 27 \mathrm{~cm}$. 


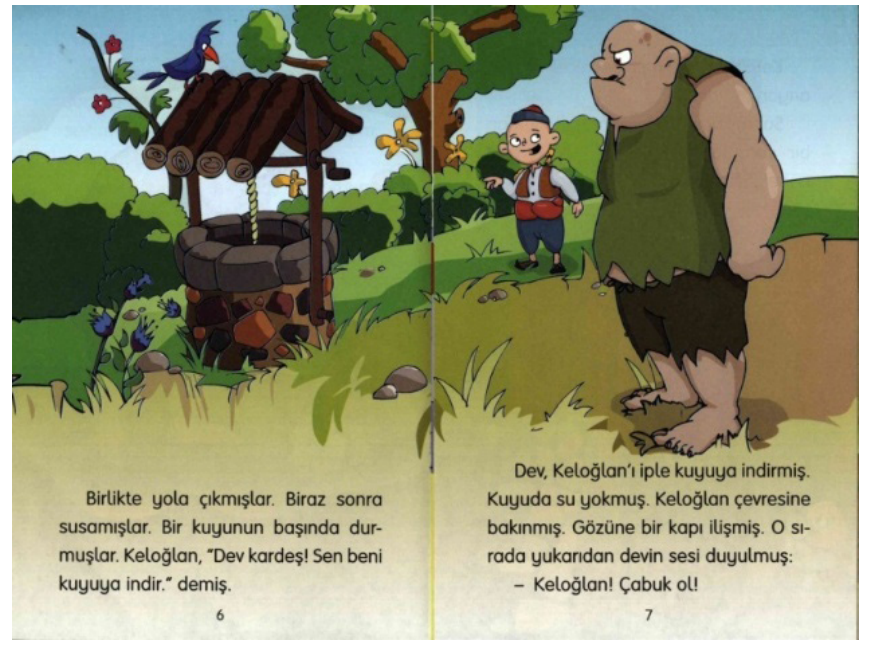

Resim 12. Muhterem Tortop-Duygu Malatyalığlu-Anıl Tortop, Keloğlan'ın Rüyası Masal Kitabı, 2008, Bilgisayar, I 4 × 24 cm.

\subsubsection{Baskı ve Cilt Kalitesi}

Genel anlamda akademisyen ve illüstratörler baskı ve cildin iyi olmadığını fakat kâğıt seçiminin doğru yapıldığını, iç sayfaların kuşe kâğıt olduğunu, hedef kitleye kalite duygusu verdiğini, bazı sayfa tasarımlarında kesim hatalarının yapıldığını ve hiçbir çizerin çalışmasının kesilmeyi hak etmediğini, baskı ve cilt kalitesinin kitabın ömrünü uzatarak dayanıklıığını arttırdığını aktarmışlardır. Baskı ve cilt kalitesi ile ilgili olumlu bir değerlendirme yapan illüstratör 5 şunları söylemiştir: "Keloğlan Hazine Arıyor (Resim 6), masal kitabındaki baskı ve cilt kalitesi çok iyi, kapağın gramajı yüksek, sıra dışı bir biçimdedir; iç sayfalar da yüksek gramajı kağıt olup, fazlasıyla baskı ve cilt kalite duygusu vermektedir."Akademisyen 5 'in ise, "Keloğlan Solmayan Güller Çocuk Kulübü (Resim 5), masal kitabında baskılarda kesim hataları var. Ama genel duruma baktığımızda iyi" açıklaması dikkat çekicidir. Akademisyen 1'in "Keloğlan ile Geyik Yavruları (Resim 8), Keloğlan ve Solmayan Güller Çocuk Kulübü (Resim 5), masal kitabındaki baskı ve cilt kalitesi vasattır. İç sayfalar 1.hamur kâğıt olup, kalite duygusu vermemektedir" ifadesi dikkat çekicidir.

\section{Sonuç, Tartışma ve Öneriler}

\subsection{Tartışma}

Araştırmada kullanılan görüşme formunda çeşitli bulgular elde edilmiştir. Elde edilen bulgulara göre illüstrasyonlar hedef kitlenin konuyu algılaması 
için yeterlidir. Fakat illüstrasyonlarda birçok anatomik ve teknik hatalar ve eksiklikler olduğu belirtilmektedir. Metinin görsel ifade dili olan illüstrasyonların doğru anatomi ile aktarımasının çocuklara masal karakterlerini daha sonra da masalı sevdireceği belirtilmektedir.

Ankete katılanlar tarafından, Keloğlan masal kitaplarının iç sayfalarında kullanılan kâğıtlara göre kapaktaki kâğıdın gramajının daha kalın olması gerektiği belirtilmektedir. Yayınevlerinde kitabın dayanıkılı̆̆ından çok kitabı nasıl daha ucuza mal ederiz düşüncesi hâkim olduğu için tutkallama yöntemini tercih ettikleri, boyut olarak da küçük oldukları ve yazım hatalarının olduğu tespit edilmiştir. Gönen, Katrancı, Uçuş ve Uygun (2011) tarafından yapılan "Türk Masallarında Renk İmgesi" konulu çalışmada incelenen masal kitaplarının boyutlarının çoğunlukla aynı ölçülerde olduğu, kapaklarının ve ciltlerinin dayanıksız olduğu, kitaplarda dil bilgisi hatalarının bulunduğu belirlenmiştir.

İncelenen Keloğlan masal kitaplarında genel olarak kültürel özelliklerinin yansıtıldığı fakat yetersiz ve eksik olduğu, illüstratörlerin bu konuda iyi bir araştırma yaparak daha doğru kültür aktarımı sağlamaları gerektiği belirlenmiştir. Mert, Albayrakve Serin (2013) tarafından yapılan araştırmada çocuk kitaplarının çocuğun bakış açısını genişletecek, merak ve keşfetme duygusunu geliştirecek, aynı zamanda yaratıcılığına katkıda bulunacak ve farklı kültürleri tanımasına, bilmediklerini keşfetmesine yardımcı olacak nitelikte hazırlanmış olması gerektiği tespit edilmiştir.

Elde edilen bulgulara göre akademisyenler ve illüstrastörler, masal yazımına ve resimlemesine başlamadan önce kitabı resimleyen ve tasarlayanların iyi bir araştırma ve gözlem yapması gerektiğini, metin yazımını ve illüstrasyonları hedef kitlenin yaş seviyesine göre yazmak ve resimlemek gerektiği bu konuda illüstratör ve yazarlara çok iş düştüğünü belirtmişlerdir. Gürpınar (2010) tarafından yapılan görsel kavramlar, illüstrasyon ve çocuk kitapları konulu araştırmada; illüstrasyonla küçük yaşta karşılaşan çocukta, gördüğünü anlatma işlevinin geliştiği, algılamasını, düşünme becerisini geliştiren resimler kadar basit dille anlatılan bir masaldan da çocuğun aynı hazzı almasının mümkün olduğu, masalın kendine öz bir üslubu olması gerektiği, illüstrasyonların çocuğun gelişim özelliklerine cevap verecek biçimde düzenlenmesi gerektiği belirlenmiştir.

Incelenen kitaplara bakıldığında anlatım dilinin sade ve akıcı bir dille yazıldığı tespit edilmiştir. Hedef kitlesi 1. ve 2. sınıf olan Keloğlan masal kitaplarının çoğunluğunun çocukların okuyabileceği ve anlayabileceği düzeyde olduğu, illüstrasyon ve metin ilişkisinin çoğu kitapta doğru olarak yansıtıldığı söylenebilir. 
Keloğlan masallarının çocukların okuma, anlama ve konuşma becerisi kazanmasına yardımcı olduğu, Türkçeyi doğru kullanmasını sağladığı, çocukların kavrama ve algılama düzeyini arttırdığı bunun içinde metinin çocukların okuyabileceği punto ve karakterde olması gerektiği tespit edilmiştir. Karatay (2007) tarafından yapılan araştırmada ise sözlü edebiyat ürünü olan masalın; dil edinimi, millî ve evrensel kültür değerlerinin kazanılması sürecinde öğrencilere okuma, dinleme, yazma, konuşma ve hatta görsel okuryazarlık becerilerinin kazandırılması için öğretme ve öğrenme sürecinde kullanılması gereken önemli öğretim materyalleri arasında yer aldığı belirtilmiştir.

Renk konusunda renk tercihinin daha doğru ve renk seçiminin daha fazla olabileceği, çocukların bilinen renklerin dışında da renk tonlarının olduğunu öğrenmesinin hayal dünyalarına katkı sağlayacağı, bunun için masalın iyi bir araç olduğu, masal kitaplarında örneğin, kırmızı renge farklı renk tonları eklendiğinde daha sanatsal ve etkileyici bir ton elde edildiği tespit edilmiştir. Orçan (2011) Türk masallarında renk imgesinin araştırıldığı araştırmada renk imgesi bağlamında belli bir zenginliğin olduğu, ancak günümüz yazınıyla karşılaşıldığında imgesel sunumun, duyusal ifadenin, renk adı kullanımındaki çeşitliliğin az olduğu, renklerin en temel beş renk arasında kullanıldığı vurgulanmaktadır. Varlığına hiç rastlanmayan veya az görülen renklerin de mevcut olduğu söylenebilir.

Araştırma bulgularına göre Keloğlan masal kitaplarında kitap isimlerinin ve metinin birbiri ile bütünlük sağladığı, bazı kitaplardaki başııkların daha farklı yazı karakteri kullanılarak okunaklılığının ve dikkat çekiciliğinin arttıııması gerektiği, arka fonyazı ilişkisinde aynı renk tercih edildiğinde yazının okunmadığı ve dikkat çekici olmadığı belirtilmiştir. Gönen, Aydos, Şentürk, Karacan, Kahraman, Tuna (2013) tarafından yapılan araştırmada kitaplarda konu ve başlık uyumunun dikkat edilmesi gereken bir özellik olup kitapların bazılarında bu uyuma rastlanmadığı ve başlığın dikkat çekici olmasına özen gösterilirken bazen konu ile uyumun göz ardı edildiği belirlenmiştir.

Incelenen masal kitaplarında yer alan masal karakterlerinin genel anlamda özgün olduğu fakat çocukların seveceği ve etkileneceği tarzda çizilmediği, çocukların kendine örnek aldığı karakterlerin daha yaratıcı ve sevimli olması gerektiği tespit edilmiştir.

\subsection{Sonuç}

Akademisyen ve illüstratörlere uygulanan 10 soruluk görüşme formu sonuçlarında ortaya çıkan veriler doğrultusunda; ele alınan masal kitaplarında illüstrasyonların masal metinlerini desteklediği ancak bazı 
kitaplardaki görsellerin metni desteklemekte yetersiz kaldığı, kitapların bazıların da anlatımın doğru bir biçimde ifade edilmediği sonucuna ulaşılmıştır. Akademisyenlerveillüstratörler, çocukların beğenisinikazanması için illüstrasyonların anatomi, renk, özgünlük yönünden iyi tasarlanması ve günümüz grafik sanatı anlayışına uygun olması gerektiğini belirtmişlerdir.

illüstrasyonlarda figürlerin mekân ile ilişkisinin kurulması ve illüstrasyonlardaki öğeler arasındaki oran-orantı ilişkisinin doğru resmedilmesi gerektiği, kitabın kapağındaki illüstrasyonun dikkat çekici olması ve iç sayfalarda yer alan illüstrasyonların konuyu desteklemesi gerektiği, illüstrasyonlarda kullanılan renklerin hedef kitlenin yaşına uygun seçilmesi açısından kısmen uygun olduğu, karakterlerin çok amatör olduğu ve bu konuda illüstratörlerin daha dikkatli ve özgün masal karakterleri yaratması gerektiği sonucuna ulaşılmıştır. İlüstrasyonlarda ve mekanda kullanılan renklerin çocukların dikkatini çekecek onları daha farklı hayal dünyalarına götürecek tonlarda olması gerektiği, illüstrasyon ve metin ilişkisinin birbiriyle bütünlük içinde olması gerektiği, mekan çiziminde perspektif kuralına daha fazla dikkat edilmesi gerektiği sonucuna ulaşılmıştır.

Masal tiplemelerinde birebir kopyala yapıştır mantığı olduğu, bazı kitaplarda figürlerin vücut ve el oranlarında anatomik hatalar olduğu bu olumsuzlukların çocukları kitap okumaktan soğutacağı ifade edilmiştir. Görüşmeye katılan akademisyen ve illüstratörler, Türkiye'de yayınlanan Keloğlan masal kitapları illüstrasyonlarının Avrupa ülkelerinde yayınlanan çocuk masal kitapları kadar başarılı olmadığını, Keloğlan karakterinin yıllarca tekrarlanan aynı karakterlerin çizgileri olduğunu belirtmişlerdir. Masal kitaplarında özgünlük kavramının tam olarak yansıtılmadığı, tasarımların kopya edildiği, bilgisayarın kolaylığından yararlanılarak hazır bilgisayar motiflerinin kullanıldığı, bunun yerine Türk kültüründen motiflerin kullanılması gerektiği, kahramanları özgün olan kitaplarda çizimlerin hatalı ve niteliksiz olduğu, çocukların gözünden kaçmayacak oran-orantı hatalarının yapıldığı, Keloğlan karakterinin herkes tarafından bilinen, üzerinde çok fazla değişiklik yapılamayacak bir tipleme olduğu ancak yan karakterlerin daha özgün yaratılabileceği, öne çıkan akademisyen ve illüstratör görüşleridir.

Araştırmada hedef kitlesi 1.ve 2. sınıf olan Keloğlan masal kitaplarında yazı fontu ve punto seçiminin daha özenli ve doğru yapılması gerektiği, değerlendirilen bazı kitaplarda puntonun küçük, kapak yazı karakterinin çok zayıf ve metnin yazı karakteri ile uyumlu olmadığı sonucuna ulaşılmış, bu konuda illüstratör, yayınevi ve grafik tasarımcının mutlaka işbirliği içinde 
olması gerektiği belirtilmiştir.

İllüstratör ve akademisyenler kitaplarda merhamet, yardımlaşma, paylaşma, vefa gibi kültürel kavramların yanı sıra insani değerleri ifade eden arkadaşlık, dostluk, sevgi kavramlarına kısmen de olsa yer verildiğini fakat yeterli olmadığını belirtmişler. Yazarın metinde anlatması gerekeni illüstratörün de görselde sunmasının çocukların masalı anlama ve kavramasında etkili olduğunu ifade etmişlerdir.

Akademisyen ve illüstratörler, baskı ve cilt kalitesinde gerekli özenin gösterilmediğini, çocuklara kitap okumak ve masalı sevdirmek hedefleniyorsa, MEB'nın çocuk yayınları konusunda uzman yayınevleri, profesyonel eğitimciler, çocuk edebiyatı yazarları, profesyonel illüstratörler, uzman grafik tasarımcılarla çalışması gerektiğini ve her çocuğun hakları ile doğduğunu bu hakların içerisinde güzel ve kaliteli masal kitaplarına sahip olma hakkının da olduğunun unutulmaması gerektiğini önermişlerdir.

\section{3. Öneriler}

Bu bölümde Türkiye'de 1. ve 2.sınıf seviyesindeki çocuklara yönelik tasarlanan ve basılan Keloğlan masal kitaplarının nasıl daha nitelikli olabileceğine ilişkin önerilere yer verilmiştir. illüstratör ve yazar ilk olarak araştırma yapmalıdır. Yazar masal metinlerini çocukların yaş seviyesine uygun okunaklı yazmalı illüstratör ise illüstrasyonları çocukların yaşına uygun, algılaması kolay, sevimli, etkileyici ve akılda kalıcı bir biçimde çizmelidir. Metinlerin anlatım dili ile illüstrasyonların görsel ifade biçimi bütünlük içinde olmalıdır. Çocuklar metinde anlatılanla görsel arasında yanılgıya düşürülmemelidir. Metini okuyamayan çocuk illüstrasyona bakarak da bir şeyler öğrenebilmelidir.

Keloğlan masal kitaplarındaki illüstrasyonlar incelendiğinde estetik ve sanattan yoksun tasarımlar olduğu, yazı fontu ve puntosunun hedef kitle profiline uygun olmadığı, rengin bilinçli kullanılmadığı görülmüştür. Nitelikli ve özgün masal kitapları için yayınevlerine düşen görev, masal kitabı resimlemesi alanında uzman illüstratörlerle çalışılmasıdır.

Renk masal kitabındaki en önemli öğelerden biridir. Kitabın arka fon rengi, tipografinin rengi, illüstrasyonların rengi bütünlük içinde olmalıdır. Renklerin çocuklar üzerindeki etkisi düşünülerek, rengin boya tüpünden çıktığı haliyle değil, farklı renklerle karıştırılarak kullanılması kitabı sıkıcılıktan kurtaracak, daha sanatsal ve estetik yapacaktır.

İllüstrasyon ve metnin sayfada bütünlük sağlamadığı, Keloğlan masal kitaplarıyla karşılaşılmıştır. Bu sorunu ortadan kaldırmak için illüstratör ve 
grafik tasarımcı birlikte çalışmalıdır.

Masal kitaplarının dayanıklı ve uzun ömürlü olması için yayınevleri karton kapakları tercih etmelidir.

Ileride yapılacak çalışmalarda Keloğlan masal kitaplarının çocuklar üzerindeki etkisi araştırılabilir. 


\section{Kaynakça}

Arıcı, A, F. (200I). Illköğretim Üçüncü Sınıf Türkçe Ders Kitaplarındaki Masalların Öğrenci Eğitimine Katkıları. Yayımlanmamış Yüksek Lisans Tezi, Atatürk Üniversitesi Sosyal Bilimler Enstitüsü, Erzurum.

Arslan, Ş. (2008). IIlköğretim I.Kademe Birinci Sınıf Matematik-Türkçe ve Hayat Bilgisi Ders Kitaplarındaki Illüstrasyonların Grafiksel Açıdan Incelenmesi. Yayımlanmamış Yüksek Lisans Tezi, Abant İzzet Baysal Üniversitesi Sosyal Bilimler Enstitüsü, Bolu.

Çetinkaya, Z. (2007). Masalların Türkçe Öğretimindeki Yeri ve Önemi. Yayımlanmamış Doktora Tezi, Dokuz Eylül Üniversitesi Eğitim Bilimleri Enstitüsü, İzmir.

Gezer, A. (2006). Soyut Kavramların Öğretiminde Hayvan Masallarının Yeri. Yayımlanmamış Yüksek Lisans Tezi, Marmara Üniversitesi Eğitim Bilimleri Enstitüsü, ístanbul.

Harmancı, M. (2010). Türk Masallarında Keloğlan Tipi. Yayımlanmamış Doktora Tezi. Kocaeli Üniversitesi Sosyal Bilimler Enstitüsü, İzmit.

Işıklı, S. (20/2). Grafik Tasarımda Logo ve Amblemin Sektörlere Göre Renk Algısı. Yayımlanmamış Yüsek Lisans Tezi.Haliç Üniversitesi Sosyal Bilimler Enstitüsü, İstanbul.

Karatay, H. (2007). "Dil Edinimi ve Değer Öğretimi Sürecinde Masalın Önemi ve İşlevi." Türk Eğitim Bilimi Dergisi, 5(3), 463-475.

Özkan, A. (2008). Karakter Özellikleri İtibariyle Erzincan Masallarındaki Tiplemeler, Yayımlanmamış Yüksek Lisans Tezi, Selçuk Üniversitesi Sosyal Bilimler Enstitüsü, Konya.

Sakaoğlu, S. (20/2). Masal Araştırmaları. Ankara: Akçay Yayınları.

Sarıkaya, B. (2004). Türk Masallarında Aile Yapısı. Yayımlanmamış Yüksek Lisans Tezi, Sakarya Üniversitesi Sosyal Bilimler Enstitüsü, Sakarya.

Şimşek, E. (2006). "Masalların Sembolik Dili Bağlamında Keloğlan Tipi Üzerine Bir Değerlendirme. "VII. Milletlerarası Türk Halk Kültürü Kongresi, Gaziantep.

Türk Dil Kurumu. (2005). Türkçe Sözlük. Ankara: TDK.

Tural, S. Veliyev K, \& Göçgün. Ö. (2002). Türk DünyasıEdebiyat Tarihi, Ankara: Atatürk Kültür Merkezi.

Uçar, F. T. (2004). Görsel Illetişim ve Grafik Tasarım. İstanbul: Inkılap Yayınevi.

Ünen, Z.Y. (2012). Okul Öncesi Çocuk Hikaye Kitaplarındaki Illüstrasyonların Biçim Dili. Yayımlanmamış Yüksek Lisans Tezi, Haliç Üniversitesi Sosyal Bilimler Enstitüsü, İstanbul. 
Yılmaz, G. (2010). Çocukta Mekan Algııının Gelişiminde Masalın Etkisi/Önemi. Yayımlanmamış Yüksek Lisans Tezi, Dokuz Eylül Üniversitesi Fen Bilimleri Enstitüsü, İzmir.

\section{Görsel Kaynaklar}

Resim I. Tortop, M. Malatyalıoğlu, D. ve Tortop, A. (2008). Keloğlan Avcı Masalı, Top Yayıncilık: izmir.

Resim 2. Alangu, T. ve Delioğlu, M. (2013). Keloğlan Masalları Kitabı, Yapı Kredi Yayınları: istanbul.

Resim 3. Bilir, O. ve Yiğit V. (2013). Kargalar Şahı Masal Kitabı, Kuşak Yayınları: İstanbul.

Resim 4. Turan, E. ve Çizgiötesi, A. (2010). Keloğlan ile Geyik Yavruları Masal Kitabı, Parıltı Yayıncilik: istanbul.

Resim 5. Gümüş, G. ve Çilesiz, Y. (2006). Keloğlan ve Solmayan Güller Çocuk Kulübü Masal Kitabı, Çıra Çocuk: İstanbul.

Resim 6. Bektaş, E. ve Acar, M. (20/2). Keloğlan Hazine Arıyor Masal Kitabı, Nakkaş Yayınları: istanbul.

Resim 7. Bilir, O.ve Yiğit V. (20/3). Kargalar Şahı Masal Kitabı, Kuşak Yayınları: İstanbul.

Resim 8. Turan, E. ve Çizgiötesi, A. (2010).Keloğlan ile Geyik Yavruları Masal Kitabı, Parıltı Yayıncilik: istanbul.

Resim 9. Bektaş, E. ve Acar, M. (20/2). Keloğlan Hazine Arıyor Masal Kitabı, Nakkaş Yayınları: Istanbul

Resim 10. Gümüş, G. ve Çilesiz, Y. (2006). Keloğlan ve Solmayan Güller Çocuk Kulübü Masal Kitabı, Çıra Çocuk: İstanbul.

Resim II. Bilir, O. ve Yiğit V. (20/3). Kargalar Şahı Masal Kitabı, Kuşak Yayınları: İstanbul.

Resim 12. Tortop, M., Malatyalığlu, D. ve Tortop, A. (2008).Keloğlan'ın Rüyası Masal Kitabı, Top Yayıncılık: İzmir. 